\title{
Relationships among phenology, climate and biomass across subtropical forests in Argentina
}

\section{Cecilia Blundo ${ }^{1}, *$, Nestor I. Gasparri ${ }^{1}$, Agustina Malizia ${ }^{1}$, Matthew Clark ${ }^{2}$, Genoveva Gatti ${ }^{3}$, Paula I. Campanello ${ }^{3,4}$, H. Ricardo Grau ${ }^{1}$, Leonardo Paolini ${ }^{1}$, Lucio R. Malizia ${ }^{5}$, Sandra E. Chediack ${ }^{6}$, Patricio MacDonagh ${ }^{7}$ and Guillermo Goldstein ${ }^{8}$}

\author{
${ }^{1}$ Instituto de Ecología Regional, Universidad Nacional de Tucumán. CONICET. Yerba Buena, Argentina \\ ${ }^{2}$ Center for Interdisciplinary Geospatial Analysis, Department of Geography, Environment and Planning, Sonoma State University, CA, USA \\ ${ }^{3}$ Instituto de Biología Subtropical, Facultad de Ciencias Forestales, Universidad Nacional de Misiones. CONICET. Puerto Iguazú, Argentina \\ ${ }^{4}$ Centro de Estudios Ambientales Integrados, Universidad Nacional de la Patagonia San Juan Bosco, CONICET. Esquel, Argentina (Present address) \\ ${ }^{5}$ Centro de Estudios Territoriales Ambientales y Sociales, Facultad de Ciencias Agrarias, Universidad Nacional de Jujuy. San Salvador de Jujuy, Argentina \\ ${ }^{6}$ Investigadora independiente. San Cristóbal de las Casas, Chiapas, México \\ ${ }^{7}$ Facultad de Ciencias Forestales, Universidad Nacional de Misiones. Eldorado, Argentina \\ ${ }^{8}$ Laboratorio de Ecología Funcional, Universidad de Buenos Aires. CONICET. Buenos Aires, Argentina \\ (Received 12 January 2017; revised 6 March 2018; accepted 6 March 2018)
}

\begin{abstract}
Phenology is a key ecosystem process that reflects climate-vegetation functioning, and is an indicator of global environmental changes. Recently, it has been suggested that land-use change and timber extraction promote differences in forest phenology. We use remote-sensing data to describe regional leaf phenological patterns in combination with field data from 131 plots in old-growth and disturbed forests distributed over subtropical forests of Argentina $\left(54-65^{\circ} \mathrm{W}\right)$. We assessed how climate is related to phenological patterns, and analysed how changes in forest structural characteristics such as stock of above-ground biomass relate to the observed phenological signals across the gradient. We found that the first three axes of a principal component analysis explained $85 \%$ of the variation in phenological metrics across subtropical forests, ordering plots mainly along indicators of seasonality and productivity. At the regional scale, the relative importance of forest biomass in explaining variation in phenological patterns was about 15\%. Climate showed the highest relative importance, with temperature and rainfall explaining Enhanced Vegetation Index metrics related to seasonality and productivity patterns ( $27 \%$ and $47 \%$, respectively). Within forest types, climate explains the major fraction of variation in phenological patterns, suggesting that forest function may be particularly sensitive to climate change. We found that forest biomass contributed to explaining a proportion of leaf phenological variation within three of the five forest types studied, and this may be related to changes in species composition, probably as a result of forest use.
\end{abstract}

Key Words: biomass, climate, enhanced vegetation index, MODIS, permanent plots, phenology, subtropical forests

\section{INTRODUCTION}

The timing and green-up of vegetation are key ecosystem responses that reflect climate-vegetation functioning, and have become emerging indicators of global environmental changes (Clark et al. 2001). Leaf phenology is strongly related to temperature in middle and high latitudes climates, and to rainfall in seasonally dry climates (Zhang et al. 2006). A recent study in

\footnotetext{
*Corresponding author. Email: ccblundo@gmail.com
}

the Amazon has shown that the southern equatorial regions have a distinctive canopy phenology with net leaf flush being responsive to seasonality in solar irradiance, and also to variation in dry-season length (Jones et al. 2014). Therefore, leaf phenology might be expected to be one of the most easily observable ecosystem functions that change in response to climate.

Relationships between phenological variation with climate (van Leeuwen et al. 2010, Zhang et al. 2005) and vegetation communities (Davison et al. 2010) can be analysed through remote-sensing analysis. Recent 
studies have suggested differences in phenological patterns of vegetation in relation to land-use change in temperate and tropical regions (de Beurs \& Henebry 2004, Suepa et al. 2016), and in response to timber extraction in the Amazon forests (Koltunov et al. 2009). Across subtropical regions, phenological variation and particularly the effects of climate and disturbance on canopy leaf phenology remains largely understudied. However, subtropical forests may have large impacts on the global carbon cycle (Zhang et al. 2016). A better understanding of phenological drivers is necessary to predict potential impacts of climate change and forest use on carbon balance in subtropical regions.

Subtropical forests in South America include dry forests, seasonally deciduous forests, cloud evergreensemi-deciduous forests and moist semi-deciduous forests. Seasonal forests in north-western Argentina have experienced an increase in rainfall during the past decades (Ferrero \& Villalba 2009). At the same time, a pronounced decrease in rainy days with changes in rainfall distribution patterns is expected in moist semi-deciduous forests in the north-east (Pizarro et al. 2013), which are also experiencing an increment in mean temperatures (Salazar et al. 2007). In addition, extensive areas are affected by extensive cattle ranching, selective logging and firewood extraction, with negative effects on the forest structure, particularly a reduction in tree above-ground biomass, and changes in species composition and ecosystem functioning (Blundo \& Malizia 2009, Campanello et al. 2007).

In this study, we analysed remote-sensing data to describe phenological patterns in combination with field data from 131 permanent plots established in old-growth and disturbed forests to carry out a comprehensive regional analysis of leaf phenological patterns and their relationships with climate and forest-use along subtropical forests of South America. In particular, we assessed how rainfall and temperature are related to leaf phenological patterns across a subtropical environmental gradient, and analysed how changes in forest structural characteristics, such as stock of above-ground biomass, as a consequence of human activity relate to the observed phenological signals across the gradient. We tested the following hypotheses: (1) tree phenology will respond to rainfall in subtropical seasonal forests (Malizia et al. 2012, Suepa et al. 2016), while in humid subtropical forests leaf flushing will be associated with daylight and temperature (di Francescantonio 2017, Marques et al. 2004), and (2) changes in the stock of above-ground biomass and in the distribution of species traits, in particular, leaf phenology and wood density, will affect the phenological signal in disturbed forests.

\section{METHODS}

\section{Study area and forest types}

In South America, Atlantic forest, Chaco and Andean forest are forest types distributed from tropical areas that reach their southern limit in North Argentina. In this part of their distribution, climate is defined as subtropical because temperatures may drop considerably generating occasional frost during the cold months (Brown et al. 2001). The study area includes these three forest types which involve forests with different phenological patterns, distributed within an area of about $150000 \mathrm{~km}^{2}$ $\left(22-28^{\circ} \mathrm{S}, 54-65^{\circ} \mathrm{W}\right)$. These forests cover a wide range of altitude (from $200 \mathrm{~m}$ to $c .3000 \mathrm{~m}$ asl), rainfall (from 400 to more than $2000 \mathrm{~mm} \mathrm{y}^{-1}$ ) and mean annual temperatures (from 14 to $24^{\circ} \mathrm{C}$ ). Most of these forests experience some degree of human intervention such as extensive cattle ranching, selective logging and firewood extraction.

The Andean forest extends along an altitudinal gradient from 400 to $3000 \mathrm{~m}$ asl, and represents the southernmost extension of Neotropical montane forests located on the eastern Andean slope (Cabrera \& Willink 1980). We considered three vegetation units based on traditional floristic classification (Brown 1995): premontane forest (PF) from c. 400-900 m asl, low montane forest (LMF) from c. 900-1600 m asl, and high montane forest (HMF) from c. 1600-3000 m asl. Premontane forests are seasonal dry forests with $>80 \%$ deciduous tree species (Sarmiento 1972). Low and high montane forests are cloud forests with a high proportion of evergreen and semi-deciduous tree species (Brown et al. 2001). Rainfall is concentrated from November to March with mean values of $820 \mathrm{~mm} \mathrm{y}^{-1}\left(550-1400 \mathrm{~mm} \mathrm{y}^{-1}\right)$ in PF, $1800 \mathrm{~mm} \mathrm{y}^{-1}\left(1100-2300 \mathrm{~mm} \mathrm{y}^{-1}\right)$ in LMF, and $1100 \mathrm{~mm} \mathrm{y}^{-1}\left(800-1400 \mathrm{~mm} \mathrm{y}^{-1}\right.$ ) in HMF (Bianchi \& Yáñez 1992). In cloud forests, water input through fog interception can equal direct rainfall (Hunzinger 1997). Mean annual temperature decreases along the altitudinal range from $21.5^{\circ} \mathrm{C}$ to $11.7^{\circ} \mathrm{C}$ (Arias \& Bianchi 1996).

The dry Chaco forest (DCF) covers a significant area of Bolivia, Paraguay and Argentina. It is a seasonal dry forest with vegetation dominated by broad-leaved, deciduous or semi-deciduous trees, with temperate floristic affinities (Pennington et al. 2009). A sub-humid monsoonal rainfall pattern $\left(400-900 \mathrm{~mm} \mathrm{y}^{-1}\right)$ and very high absolute temperatures $\left(48^{\circ} \mathrm{C}\right)$ create a marked water deficit in this forest type (Prado 1993), mainly from September to November.

The Atlantic forest includes from semi-deciduous to evergreen forests distributed along $3300 \mathrm{~km}$ of the Atlantic coast of Brazil, south-eastern Paraguay 


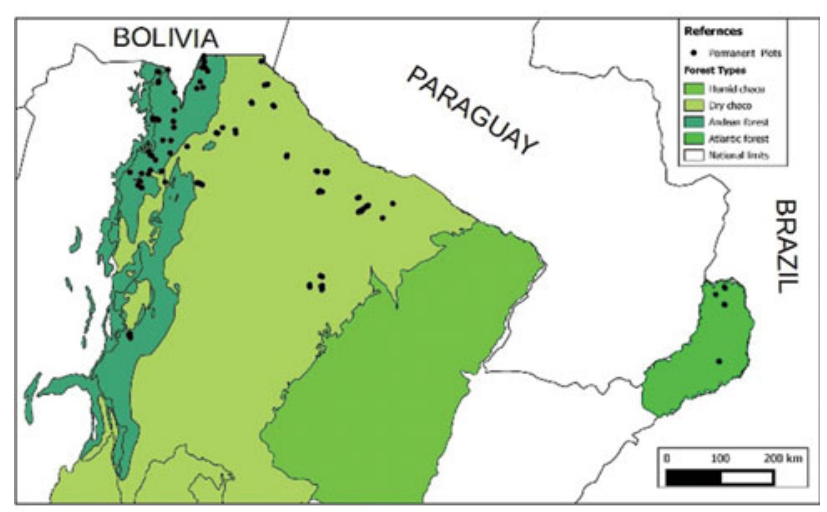

Figure 1. Location of 131 permanent plots across forest types in north Argentina.

and north-eastern Argentina (Galindo-Leal \& Gusmão Câmara 2003). Nearly $11000 \mathrm{~km}^{2}$ of semi-deciduous Atlantic forests $(\mathrm{SAF})$ remains in the north-eastern corner of Argentina and represents the largest remnant of continuous semi-deciduous Atlantic Forest. This semideciduous forest contains deciduous, brevi-deciduous and evergreen tree species, with deciduous accounting for $25-50 \%$ of the tree species (Leite \& Klein 1990). Many of the species are also present in seasonally dry forests in South America (Pennington et al. 2009, Werneck et al. 2011). Mean annual precipitation in this area is about $2000 \mathrm{~mm} \mathrm{y}^{-1}$ evenly distributed but with unpredictable dry spells occurring throughout the year. Mean annual temperature is $21^{\circ} \mathrm{C}$ with monthly means of $25^{\circ} \mathrm{C}$ in warmest month (January), and $15^{\circ} \mathrm{C}$ in coldest month (July). Frost seldom occurs in colder months.

\section{Field sampling}

We used data from 131 permanent plots (Figure 1). Plots were established in old-growth forests and disturbed forests, which have had some degree of human intervention in the last decades. In Andean forests, the traditional forest-uses were extensive cattle ranching and selective logging, but their intensity changes along the altitudinal gradient. In DCF, cattle ranching and selective logging were also the principal uses, in addition to firewood extraction from local communities. The predominant use in the SAF was selective logging and plots inside protected areas did not have human intervention in the last $70 \mathrm{y}$. Difference in above-ground biomass between plots in oldgrowth forest and plots in disturbed forest were significant for all forest types except HMF (Appendix 1).

In each permanent plot all living woody stems (such as trees, palms and ferns) $\geq 10 \mathrm{~cm}$ of diameter at breast height (dbh) were measured and identified to species. In Andean forests, 20 1-ha plots were established in PF, 16 1-ha plots and one 6-ha plot in LMF, and 14 1ha plots and 10 0.24-ha plots in HMF, all distributed between $22-27^{\circ} \mathrm{S}$ and measured between 2002 and 2008. The form of plots was square $(100 \times 100 \mathrm{~m})$ or rectangular $(20 \times 500 \mathrm{~m}$ or $40 \times 60 \mathrm{~m})$. Regardless of the plot size, all trees with $>10 \mathrm{~cm}$ dbh were marked with numbered aluminium tags, measured for dbh (1.30 m height, avoiding trunk irregularities) and identified to species or morphospecies level in every plot. In DCF, the sample unit was a $100 \times 100$-m cluster with a set of circular concentric plots placed at each vertex (Gasparri \& Baldi 2013). In one of these plots (with an area of $500 \mathrm{~m}^{2}$ and a radius of $12.6 \mathrm{~m}$ ) all trees with a $\mathrm{dbh}>10 \mathrm{~cm}$ were recorded; in other plots (area of $1000 \mathrm{~m}^{2}$ and radius of $17.8 \mathrm{~m}$ ), trees with $\mathrm{dbh}>20$ $\mathrm{cm}$ were recorded. In summary, 50 plots that represent a surveyed area of 20 ha were established during 2007. In SAF, 20 1-ha permanent plots of $100 \times 100 \mathrm{~m}$ were established between 2000 and 2003, in which all living stems $\geq 10 \mathrm{~cm}$ dbh were recorded and marked, with the exception of lianas.

\section{Above-ground biomass estimation and climatic data}

For each plot we estimated above-ground biomass using equations developed by Chave et al. (2005) for humid and dry forests. We obtained wood density for each species using local databases (Easdale et al. 2007, http://www. inti.gov.ar/), or an international database when local data were unavailable (Chave et al. 2006). If published data of wood density did not exist for a particular species we used the following criteria: (1) we used the wood density information from the species of the same genera growing in the closest geographic location (e.g. to estimate the biomass of Solanum grossum we used the wood density of Solanum riparium); (2) alternatively, we used the wood density data for the genus reported in Chave et al. (2006), and (3) if this was not possible we used the data reported for the family. If the tree individual was unidentified to species level but we knew either the genus or family ( $12 \%$ of total individuals measured) we also used the wood density data from Chave et al. (2006). Finally, if the individual was unidentified to any taxonomic level $(0.4 \%$ of total individuals measured) we used the average value of wood density of the plot where that particular tree occurred. In order to estimate above-ground biomass for palms and ferns we used the equation developed by Frangi \& Lugo (1985) and Weaver (2000), respectively. The biomass distribution pattern showed that Atlantic and Andean forests presented highest above-ground biomass per plot than dry Chaco forests $(F=49.2 ; \mathrm{P}<0.0001)$ 

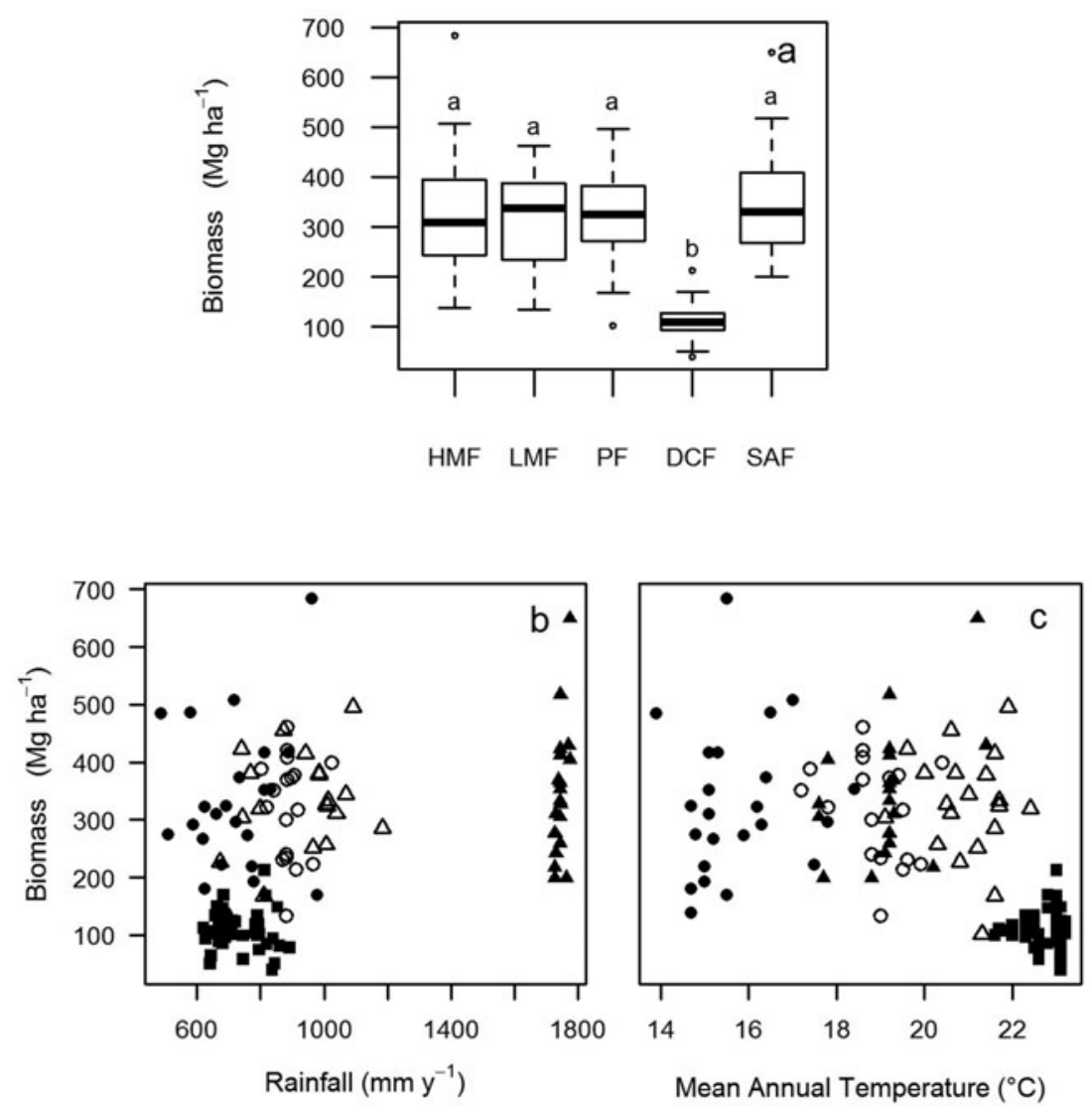

Figure 2. Boxplot of biomass against forest types (a). Lowercase letters indicate significant differences among forest types. Forest types are ordered according to the geographic gradient from west to east: high montane forest (HMF); low montane forest (LMF); premontane forests (PF); dry Chaco forest (DCF); and semi-deciduous Atlantic forest (SAF). Scatterplots of biomass against total annual rainfall (b) and mean annual temperature (c). Symbols represent plots located in HMF (black circles); LMF (white circles); PF (white triangles); DCF (black squares); and SAF (black triangles).

(Figure 2a). The phenological classification of species in deciduous, semi-deciduous and evergreen species was made with literature data (Custódio Talora \& Morellato 2000, Legname 1982, Lima Pilon et al. 2015, Martín et al. 1997) and observational data.

We obtained climatic data (mean annual temperature and rainfall) from the global database WorldClim for each permanent plot (Hijmans et al. 2005). Because of high collinearity among explanatory variables (i.e. biomass and climatic factors) can lead to relationships that are difficult to interpret when using multiple regression models, low correlations among explanatory variables are desirable. In our study, biomass correlated negatively with temperature $(r=0.57 ; \mathrm{P}<0.0001)$ and positively with rainfall $(r=0.39$; $\mathrm{P}<0.0001)$, which can be considered moderate correlation values, which need to be addressed in interpreting the results but do not invalidate them. In DCF, where the mean annual temperature is higher in combination with low levels of rainfall, the relationship between biomass and climatic factors showed less variation among plots in comparison to the moister forest types (Figure 2b, c).

\section{Remote-sensing data and phenological metrics}

MODIS images from 16-day composite time-series at 250$\mathrm{m}$ resolution were used to derive land-surface phenological metrics from Enhanced Vegetation Index (EVI). We used the TIMESAT program (Jönsson \& Eklundh 2004) to process EVI data from Julian day 289 year 2000, to Julian day 273 year 2008 (23 points $\mathrm{y}^{-1} \times 8 \mathrm{y}=$ 184 points). TIMESAT fits local functions to the timeseries data points, and then combines these functions into a global model. Phenological metrics for each growing season are then extracted from the smoothed function, thereby reducing the influence of signal noise in the raw data. The temporal window does not align with calendar years, but allows the program to have ample data to fit a full function to the main southern hemisphere growing seasons from 2001-2002 to 20072008. A custom program was created to obtain several phenological metrics calculated for each growing season (e.g. season amplitude, peak and base value) as raster bands in a stack for each calendar year. Each image pixel was processed independently and phenological metrics 


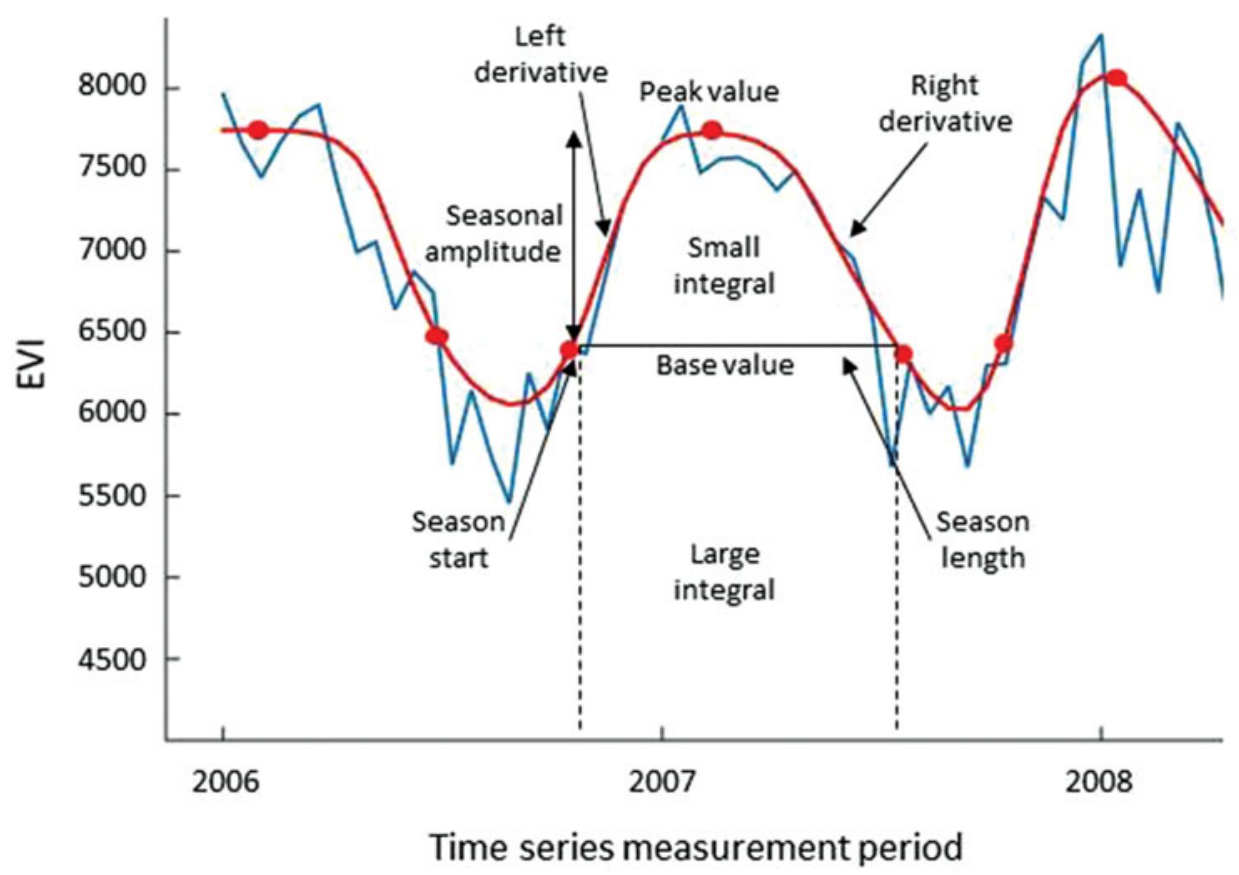

Figure 3. Nine phenological metrics derived from Enhanced Vegetation Index (EVI) time-series data using TIMESAT over $1 \mathrm{y}$ of growth in a randomly selected permanent plot. Blue curve represents real data, and red curve represents fitted model function.

were labelled with the year in which the season started. Finally, we extracted the phenological metrics for the pixel corresponding to the location of each of the 131 permanent plots. Although pixels cover a larger area than plots, we assumed that plots are representative of the surrounding vegetation (e.g. no plots were established near transformed areas). The data extracted correspond to the year of the survey of each plot, except for the case of the Atlantic forest, where the plot surveys correspond to the year 2000 and the satellite data to the year 2001.

We used nine phenological metrics from TIMESAT in our analysis: (1) season start, and (2) season length, to compare timing of vegetation growth measured in days; (3) peak value, (4) base value, (5) small integral, (6) large integral, (7) season amplitude, to account for the magnitude of EVI values; and (8) left derivative and (9) right derivative, which are related to the velocity of growth at the beginning and ending of the season growth, respectively (Figure 3). An additional variable was the coefficient between the small and large integrals that we calculated to obtain the proportion of biomass produced in the growing season. The small integral describes the vegetation production in the growth season. And the large integral, an integration of all fitted EVI values over the season, is a measure that has been related to net ecosystem production (Prince \& Goward 1995).

\section{Data analysis}

We performed a principal component analysis (PCA) to synthesize the phenological metrics in ecophysiological patterns related to productivity, seasonality and phenology (as was previously described in Davison et al. 2010), and to identify phenological groups to complement our a priori classification of plots in five forest types (i.e. HMF, LMF, PF, DCF and SAF). We used the broken-stick method to identify interpretable ordination axes (Jackson 1993). We used analysis of variance and Tukey test to describe the regional variation in the phenological patterns (i.e. significant and interpretable PC axes) among forest types. We performed multiple regression models to assess the relative importance of rainfall, temperature and biomass to explain phenological patterns across subtropical forests and within forest types. The relative importance refers to the quantification of a predictor variable's contribution to a multiple regression model. Johnson \& Lebreton (2004) defined relative importance as the proportionate contribution that each predictor makes to $\mathrm{R}^{2}$, considering both its direct effects and its effect when combined with the other variables in the regression equation. We used the $l m g$ metric (Lindeman et al. 1980) to decompose $\mathrm{R}^{2}$ into non-negative contributions that automatically sum to the total $\mathrm{R}^{2}$. The approach taken by the $\operatorname{lmg}$ metric is based on sequential $\mathrm{R}^{2}$, but takes care of the dependence on orderings by averaging over orderings, using simple 


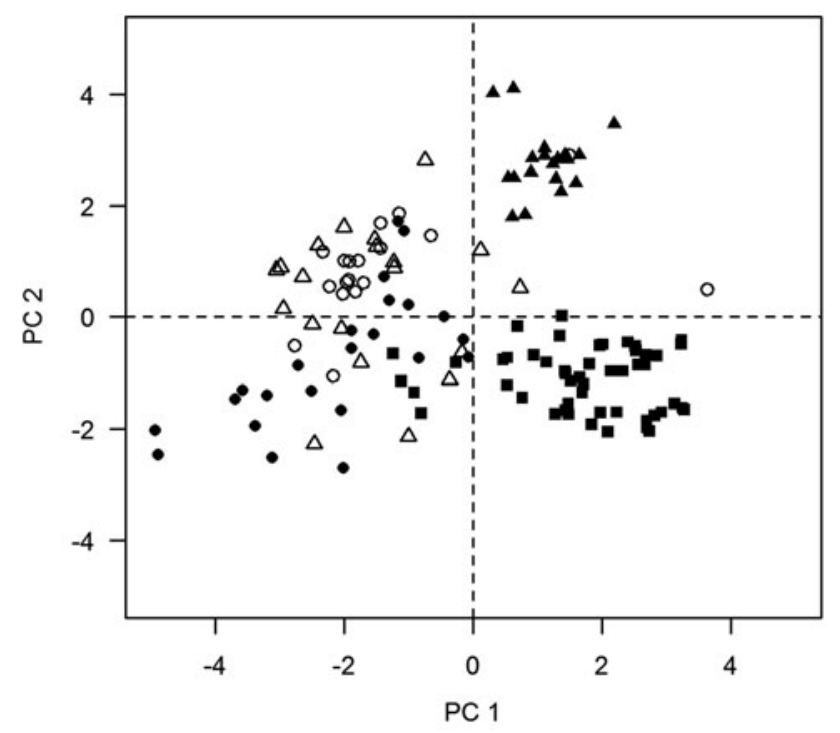

Figure 4. Principal components (PC) ordinations of 131 plots based on 10 phenological metrics. Symbols represent plots located in high montane forest (black circles); low montane forest (white circles); premontane forest (white triangles); dry Chaco forest (black squares); and semi-deciduous Atlantic forest (black triangles).

unweighted averages (Grömping 2006). Furthermore, to evaluate variation in forest structure and species composition among plots within each forest type, we performed non-metric multidimensional scaling (NMDS) to correlate plot-scores with biomass, and species-scores with leaf phenology (deciduous, semi-deciduous and evergreen) and wood density. We used R program (http: //www.R-project.org/), in particular, we used relaimpo package (Grömping 2006) to assess relative contribution of each explanatory variable and BiodiversityR package (Kindt \& Coe 2005) to multivariate analysis.

\section{RESULTS}

\section{Phenological patterns in subtropical forests}

The ordination of the 131 plots across the phenological multidimensional space based on 10 phenological metrics was congruent with the traditional biogeographic classification, differentiating the samples from the five forest types; although the differentiation between LMF and PF of the Andean forests was less clear (Figure 4). The first three PC axes were significant and explained $85 \%$ of the variation in the phenological metrics across subtropical forests sorting out plots along indicators of seasonality, productivity and phenology. The first interpretable PC (PC 1,40\%) was negatively related to seasonal amplitude, left derivative, small integral and peak value (Table 1) and distributed plots along a forest seasonality gradient. Plots with lowest scores on PC 1 showed higher values of seasonal amplitude (i.e. higher changes in EVI between dormancy and growth season), higher small integral, and higher left derivative (i.e. higher velocity of growth at the beginning of the season growth). These plots were located in Andean forests indicating that they represent the most seasonal forests (Figure 4). In addition, PC 1 was correlated positively with temperature and negatively with the biomass per plot (Table 1) showing that plots with positive scores on PC 1 (i.e. DCF) exhibited higher values of temperature and low biomass per plot. The second interpretable PC (PC 2, 26\%) was positively related to base value and large integral, and negatively related to the coefficient between integrals. Higher base and large integral values indicate that plots located in the positive scores of PC 2 present higher above-ground biomass productivity. In accordance, rainfall and biomass were correlated positively with PC 2 (Table 1 ) increasing toward plots located in SAF. Finally, the third PC (PC 3, 19\%) was positively related to season length, and negatively related to season start showing a more gradual distribution along phenological indicators mainly related to time measures. Right derivative that represents the velocity of growth in the season-end was also related with PC 3.

Regional variation in seasonality and productivity (i.e. PC 1 and PC 2, respectively) differed among forest types $(F=62.3 ; \mathrm{P}<0.0001$, and $F=60.6 ; \mathrm{P}<0.0001$, respectively), but variation in phenology did not (PC 3, $F=2.06 ; \mathrm{P}=0.09$ ). Although $\mathrm{DCF}$ and SAF were different in terms of indicators of productivity, they were the least seasonal forests given their low seasonal amplitude, left derivative and small integral relative to HMF, LMF and PF; the Andean forest types did not differ significantly in indicators of seasonality (Figure 5a-c). The SAF followed by LMF and PF showed the highest indicators of productivity consistent with high base value and high large integral (i.e. high annual GPP). Finally, although there was no significant difference in PC 3 scores among forest types, plots located in DCF (mainly) and in PF tended to show higher season length (Figure 5h).

\section{Relationships among phenological patterns, climate and biomass}

Climate showed the highest relative importance to explain variation in seasonality and productivity patterns across subtropical forests. Temperature showed higher relative importance on seasonality pattern $(27 \%)$, and rainfall showed higher relative importance on productivity pattern $(47 \%)$. In addition, variation in forest biomass showed about $15 \%$ of relative importance to explain seasonality and productivity patterns across the regional gradient (Table 2). 
Table 1. Percentage of variance explained by the principal components analysis of 131 plots established in subtropical forests of Argentina; loadings of 10 phenological metrics on the first three significant components and Spearman Rank correlations among explanatory variables with phenological metrics and PC axes. Coefficients of correlation with $\mathrm{P}<0.001$ are showed. MAT $=$ Mean Annual Temperature.

\begin{tabular}{|c|c|c|c|c|c|c|}
\hline & \multirow{2}{*}{$\begin{array}{l}\text { Seasonality } \\
\text { (PC 1) }\end{array}$} & \multirow{2}{*}{$\begin{array}{l}\text { Productivity } \\
\text { (PC 2) }\end{array}$} & \multirow{2}{*}{$\begin{array}{l}\text { Phenology } \\
\text { (PC 3) }\end{array}$} & \multicolumn{3}{|c|}{ Explanatory variables } \\
\hline & & & & Rainfall & MAT & Biomass \\
\hline Proportion of variance & $40 \%$ & $26 \%$ & $19 \%$ & & & \\
\hline Seasonal amplitude & -0.48 & -0.12 & & & -0.53 & 0.36 \\
\hline Left derivative & -0.44 & & & & -0.56 & 0.46 \\
\hline Small integral & -0.42 & -0.17 & 0.31 & & -0.34 & \\
\hline Peak value & -0.41 & 0.34 & & 0.51 & -0.64 & 0.66 \\
\hline Base value & & 0.61 & -0.10 & 0.72 & -0.40 & 0.62 \\
\hline Large integral & -0.27 & 0.42 & 0.32 & 0.57 & -0.42 & 0.56 \\
\hline Small/Large integral coefficient & -0.28 & -0.49 & 0.13 & -0.48 & & \\
\hline Season length & 0.17 & -0.11 & 0.62 & -0.39 & 0.64 & -0.56 \\
\hline Right derivative & -0.23 & -0.13 & -0.47 & & -0.39 & \\
\hline Season start & & -0.17 & -0.40 & & & \\
\hline PC 1 & & & & & 0.62 & -0.52 \\
\hline PC 2 & & & & 0.66 & & 0.53 \\
\hline PC 3 & & & & & & \\
\hline
\end{tabular}

When each forest type was analysed separately, the proportion of total variance explained, and the relative importance of each explanatory variable were different for forest seasonality, productivity and phenology. Seasonality was significantly explained only in cloud forests (i.e. HMF and LMF). Climate showed higher relative importance to explain seasonality, however rainfall was higher in HMF (32\%) and temperature was higher in LMF (25\%). Biomass showed $12 \%$ of relative importance to explain the seasonality pattern in HMF while only $4 \%$ in LMF, both with positive slopes (Table 2), i.e. plots with higher seasonal amplitude and higher left derivative (lowest scores on PC 1) tended to show higher biomass per plot. Species composition in cloud forests differed among plots as shown in the ordination analysis (Figure 6a, b), but only in HMF was there a relationship between biomass and variation in species composition along axis 1 (Appendix 2). In HMF plots with negative scores on NMDS 1 had high biomass and showed high abundance of evergreen tree species (Figure 6a).

The productivity pattern was explained mainly by climate within Andean forests (Table 2), with temperature showing the highest relative importance $(\sim 40 \%)$ in cloud forests whereas rainfall had the highest relative importance in PF (45\%). That is, within cloud forests, plots with higher mean annual temperature tend to shown higher base value and large integral, while within PF these phenological metrics increased in plots with higher annual rainfall. Only in PF did biomass show a relative importance of about $8 \%$ to explain phenological variation related to indicators of productivity (Table 2). Species composition differed in PF and this variation was correlated with biomass and foliar phenology of trees. Species scores of NMDS 1 were positively correlated with leaf phenology of tree species $(r=0.41 ; \mathrm{P}<0.001)$, and plot scores of axis 2 were negatively correlated with biomass $(r=-0.57 ; \mathrm{P}<0.01$, Appendix 2$)$. That is, plots with negative scores on NMDS 1 and NMDS 2 tended to present high biomass and showed high abundance of deciduous tree species (Figure 6c).

The third PC axis mainly related to time measures (i.e. season length and season start, both measures in days) was explained only within $\mathrm{DCF}\left(\mathrm{R}^{2}=0.24\right.$; $\mathrm{P}<$ $0.01)$ by biomass and rainfall $(11 \%$ and $9 \%$ of relative importance, respectively). Although species scores were correlated with NMDS 1 showing higher abundance of evergreen species on the positive side of this axis (Figure $6 \mathrm{~d}$ ), this variation in species composition was not related with biomass at the plot level (Appendix 2). Finally, no phenological patterns were explained either by climate or biomass in SAF (Table 2). However, plots score of NMDS 1 and NMDS 2 were correlated with biomass $(r=-0.48$ and $r=0.47$, respectively; $\mathrm{P}<0.05)$ and species scores were correlated with wood density $(r=$ $-0.40 ; \mathrm{P}<0.001$ ) showing variation in forest structure and species composition in this forest type (Figure 6e, Appendix 2).

\section{DISCUSSION}

\section{Phenological patterns across subtropical forests}

Our combined analyses of field and remote-sensing data allowed us to distinguish two principal phenological patterns across the region. On one hand, Andean forests are the most seasonal forests as indicate their higher values of seasonal amplitude. This phenological metric 

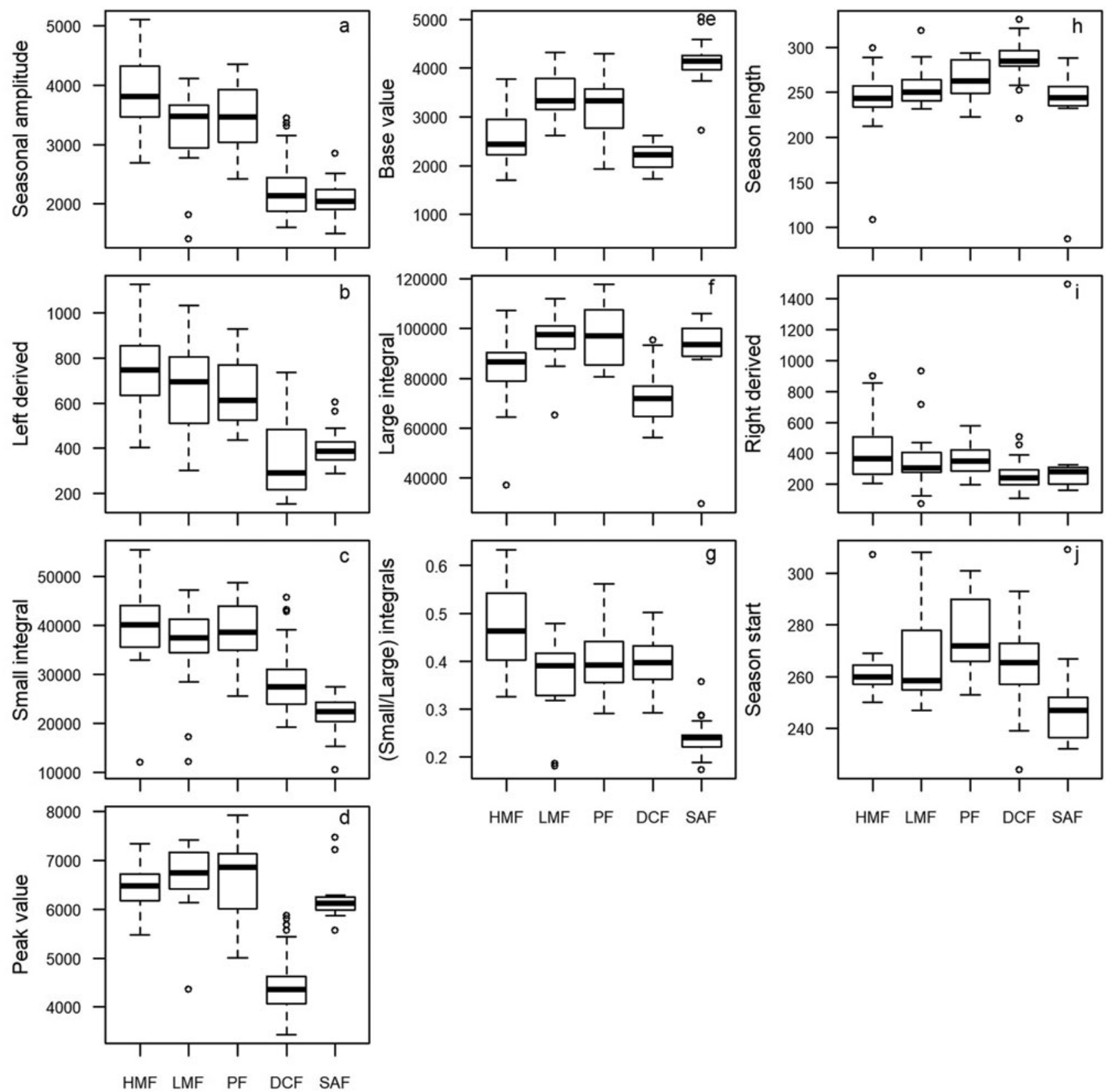

HMF LMF PF DCF SAF

HMF LMF PF DCF SAF

Figure 5. Boxplots of phenological metrics (EVI values) against forest types: (a-d) metrics related to forests seasonality, i.e. PC 1; (e-g) metrics related to forests productivity, i.e. PC 2; and (h-j) metrics related to forests phenology, i.e. PC 3. HMF = high montane forest; LMF $=$ low montane forest; PF $=$ premontane forests; $\mathrm{DCF}=$ dry Chaco forest; $\mathrm{SAF}=$ semi-deciduous Atlantic forest.

represents the change in EVI values between dormancy and seasonal growth over the year (Paruelo \& Lauenroth 1995). Subtropical Andean forests have a marked dry season which matches with colder temperatures, representing the dormancy stage. After dormancy, they start an accelerated growth during the rainy season with temperatures that may exceed $40^{\circ} \mathrm{C}$ in the lowlands; these wet and warmer conditions occur for 4-5 mo $\mathrm{y}^{-1}$ (Brown et al. 2001, Kessler \& Beck 2001). In contrast, Atlantic forest shows a precipitation pattern more evenly distributed over the year without dry season (Crespo 1982), and dry Chaco forest tends to present warmer conditions along the year. These climatic conditions without a marked dry/wet or cold/warm season in Atlantic and Chaco forests would promote lower changes in the photosynthetic activity between dormancy and growth, and consequently less change in EVI relative to Andean forests.

On the other hand, the productivity pattern in subtropical forests described along axis 2 of PCA is supported 
Table 2. Relative importance (and slope sign) estimated with the lmg metric (Lindeman et al. 1980) for each explanatory variable in multiple regression models for seasonality (PC 1), productivity (PC 2), and phenology (PC 3) patterns. Models fitted for all forests of subtropical gradient and for each forest type: HMF = high montane forest, $\mathrm{LMF}=$ low montane forest, $\mathrm{PF}=$ premontane forests, $\mathrm{DCF}=$ dry Chaco forest, $\mathrm{SAF}=$ semi-deciduous Atlantic forest. MAT $=$ mean annual temperature.

\begin{tabular}{|c|c|c|c|c|}
\hline Dataset & $\begin{array}{c}\text { Explanatory } \\
\text { variables }\end{array}$ & $\begin{array}{l}\text { Seasonality } \\
\text { (PC 1) }\end{array}$ & $\begin{array}{l}\text { Productivity } \\
\text { (PC 2) }\end{array}$ & $\begin{array}{l}\text { Phenology } \\
\text { (PC 3) }\end{array}$ \\
\hline All forests & $\begin{array}{l}\text { Biomass } \\
\text { Rainfall } \\
\text { MAT } \\
\mathrm{R}^{2} \text { (P value) }\end{array}$ & $\begin{array}{l}0.14(-) \\
0.04(+) \\
0.27(+) \\
0.45(<0.0001)\end{array}$ & $\begin{array}{l}0.15(+) \\
0.47(+) \\
0.02(+) \\
0.64(<0.0001)\end{array}$ & $\begin{array}{l}0.02(-) \\
0.02(-) \\
0.03(+) \\
0.07(0.02)\end{array}$ \\
\hline HMF & $\begin{array}{l}\text { Biomass } \\
\text { Rainfall } \\
\text { MAT } \\
\mathrm{R}^{2} \text { (P value) }\end{array}$ & $\begin{array}{l}0.12(+) \\
0.32(-) \\
0.09(+) \\
0.53(<0.001)\end{array}$ & $\begin{array}{l}0.01(+) \\
0.02(-) \\
0.41(+) \\
0.44(<0.01)\end{array}$ & n.s. \\
\hline LMF & $\begin{array}{l}\text { Biomass } \\
\text { Rainfall } \\
\text { MAT } \\
\mathrm{R}^{2} \text { (P value) }\end{array}$ & $\begin{array}{l}0.04(+) \\
0.11(-) \\
0.25(+) \\
0.40(0.06)\end{array}$ & $\begin{array}{l}0.02(+) \\
0.16(-) \\
0.42(+) \\
0.60(<0.01)\end{array}$ & n.s. \\
\hline PF & $\begin{array}{l}\text { Biomass } \\
\text { Rainfall } \\
\text { MAT } \\
\mathrm{R}^{2} \text { (P value) }\end{array}$ & n.s. & $\begin{array}{l}0.08(+) \\
0.45(+) \\
0.06(+) \\
0.59(<0.01)\end{array}$ & n.s. \\
\hline $\mathrm{CF}$ & $\begin{array}{l}\text { Biomass } \\
\text { Rainfall } \\
\text { MAT } \\
\mathrm{R}^{2} \text { (P value) }\end{array}$ & n.s. & $\begin{array}{l}0.04(+) \\
0.02(+) \\
0.08(+) \\
0.15(0.06)\end{array}$ & $\begin{array}{l}0.11(+) \\
0.09(-) \\
0.04(+) \\
0.24(<0.01)\end{array}$ \\
\hline $\mathrm{AF}$ & $\begin{array}{l}\text { Biomass } \\
\text { Rainfall } \\
\text { MAT } \\
\mathrm{R}^{2} \text { (P value) }\end{array}$ & n.s. & n.s. & n.s. \\
\hline
\end{tabular}

by the base value and the large integral. The large integral is a measure that has been related to net primary production (NPP) and net ecosystem production (Prince \& Goward 1995). The large integral and the base value are greater in semi-deciduous Atlantic forest indicating that these forests present the higher aboveground biomass production. In diverse forest ecosystems, greater leaf area index can lead to higher NPP in both dormant and growing seasons (Knapp et al. 2008). The semi-deciduous Atlantic forest has a high diversity of evergreen and semi-deciduous tree species that maintain continuous growth, and has also high potential canopy photosynthesis throughout the year (Cristiano et al. 2014). In this study, semi-deciduous Atlantic forest had the highest productivity (as indicated by base value and large integral, Figure 5e, f), with the coefficient between small and large integrals being significantly lower (i.e. the proportion of biomass produced strictly in the growing season, which is the time of the year with highest values of EVI) in comparison to other forests (Figure $5 \mathrm{~g}$ ). Indeed, only about $24 \%$ of the biomass in the Atlantic forest is produced in the growing season. The low seasonality in their climatic conditions (e.g. rainfall regularly distributed) tends to promote a relatively high biomass production throughout the year in comparison with other productive but more seasonal forests like LMF and PF. Our results show that in these two seasonal forests (i.e. LMF and PF), about $40 \%$ of the biomass is produced in the rainy season (i.e. around 4 mo in the year). At the other extreme, DCF seems to have a low but constant rate of biomass production over a longer growth season promoted by relatively warmer conditions throughout the year (Gasparri \& Baldi 2013). This dry forest also produces about $40 \%$ of its biomass in the growing season (i.e. the time of the year with highest values of EVI) as reflected by the small/large integral coefficient (Figure $5 \mathrm{~g}$ ).

Satellite-derived patterns of phenology clearly reflect differences among forest types traditionally defined on the basis of floristic composition and physiognomy. This implies that within forest types there may be common ecophysiological controls, potentially relevant for management and conservation of functional diversity, and ecological processes such as carbon storage and water availability. Phenological metrics has been proving useful to classify biomes in other studies (Wessels et al. 2011). Indicators of seasonality and productivity, such as seasonal amplitude and base value, respectively, could 


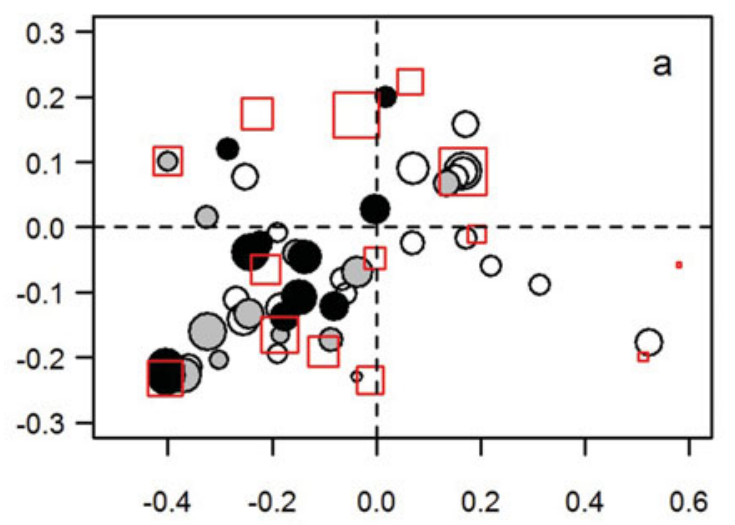
O Deciduous
O Semideciduous
- Evergreen
口 Plots
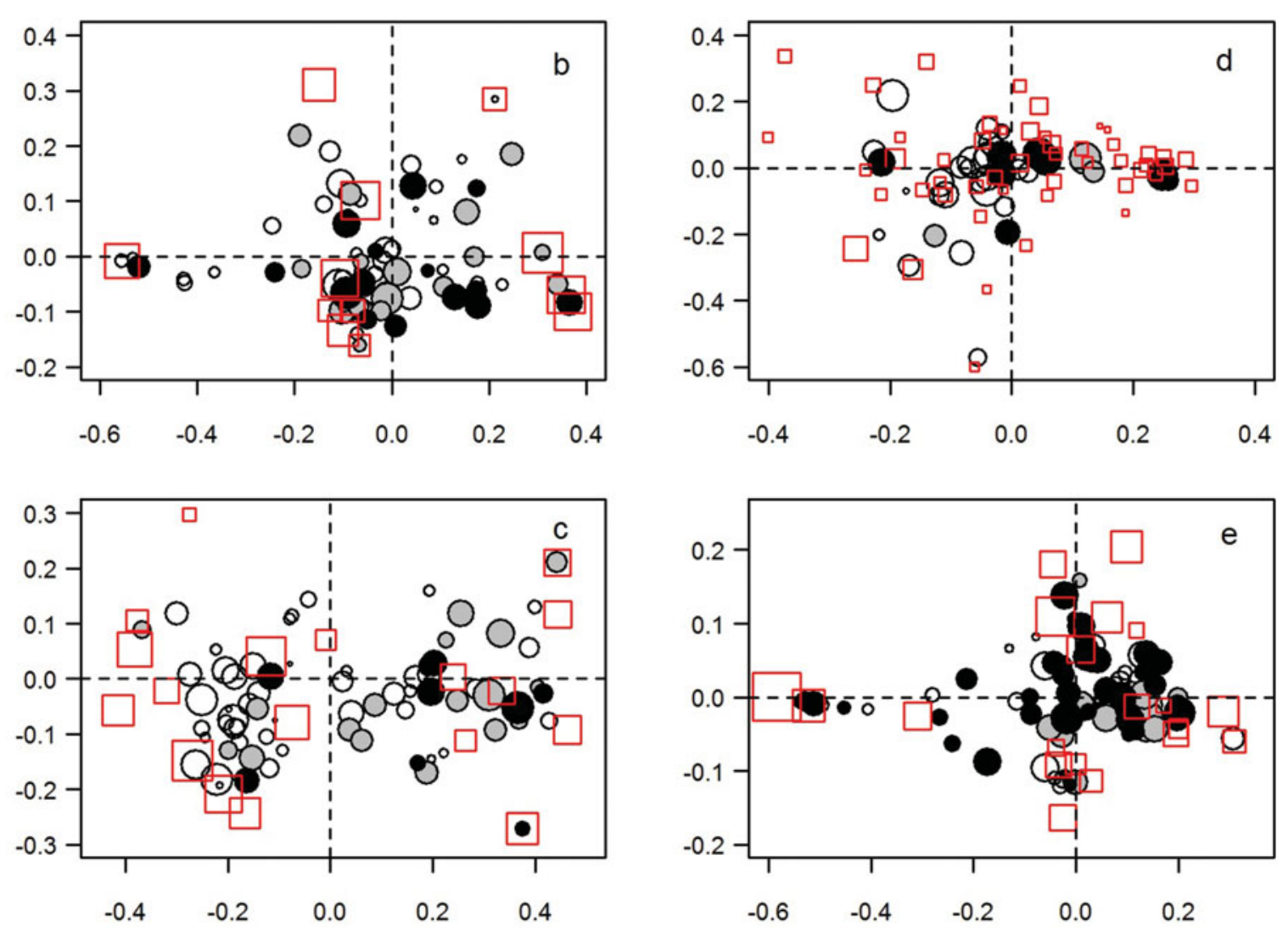

Figure 6. Species and plots NMDS ordinations for each forest type. High montane forest (a); low montane forest (b); premontane forests (c); dry Chaco forest (d); semi-deciduous Atlantic forest (e). Circles size (species) control by woody density and squares size (plots) control by biomass.

be used to map and classify forest types through remote sensing in the subtropical gradient studied.

\section{Influence of climate and biomass on phenological patterns}

We found that seasonality and productivity patterns are explained mainly by regional climatic variation and to a lesser extent by biomass; changes in the stock of biomass and the species composition in disturbed forests affect phenological signal measured through EVI metrics.
Mean annual temperature explained about $30 \%$ of forest seasonality, and annual precipitation explained about $50 \%$ of forest productivity. Many studies have reported associations between phenological metrics and regional climate (Brando et al. 2010, Linderman et al. 2005, van Leeuwen et al. 2010) indicating that EVI (or NDVI) capture spatial patterns in photosynthetic responses of vegetation to regional gradients of temperature and rainfall. In general, our results are congruent with these studies, in which changes in phenological metrics between dormancy and growing season (i.e. seasonality) 
are influenced by temperature, and the magnitude of these changes (i.e. productivity) is influenced by rainfall.

When biomass is taken into account as measure of forest structure, it adds explanatory power in the variation of phenological patterns, explaining about $15 \%$ of forest seasonality and productivity across the regional gradient (Table 2). Plant cover may represent an ecological dimension that complements phenology, seasonality and productivity in understanding landscapescale patterns and forests dynamics (Davison et al. 2010). Within forest type, climate remains relatively constant, so differences in biomass between old-growth and disturbed forest could increase the relative importance of biomass to explaining phenological patterns. In some of the forest types studied, we found that changes in forest structure and species composition in disturbed forests affect phenological metrics such as seasonal amplitude (indicator of seasonality) and base value (indicator of productivity).

We found that forest biomass contributed to explain a proportion of phenological variation within HMF, PF and DCF. In HMF, plots differ in species composition and this variation is correlated with the stock of biomass per plot. Although above-ground biomass did not differ significantly between old-growth and disturbed forests (Appendix 1), plots with higher biomass tend to have higher abundance of evergreen species, most of them belonging to the Myrtaceae, which have high wood density (e.g. Blepharocalyx salicifolius, Myrcianthes mato, M. pseudomato). In this forest type, cattle ranching is an historical anthropogenic disturbance that has been practiced by local communities in Andean forests for at least the past $100 \mathrm{y}$ (Brown et al. 2001), and is a determinant of species composition at the landscape scale (Blundo et al. 2012). Cattle ranching does not seem to reduce above-ground biomass but may affect species composition after decades of forest-use. Biomass also affects phenological metrics of forest productivity in premontane forest. Within PF, plots with higher biomass have higher abundance of deciduous species with high wood density. In PF, old-growth forests are dominated by Anadenanthera colubrina, Phyllostylon rhamnoides and Calycophyllum multiflorum, all timber species with high wood density. Biomass is significantly lower in forests disturbed by selective logging in recent decades $(F=$ 10.1; $\mathrm{P}<0.01 ; \mathrm{N}=20$ ), not only because logging decreases tree density and large trees are scarce but also because species with low wood density are promoted after timber extraction (e.g. Ocotea puberula, Chrysophyllum gonocarpum). In premontane forest, biomass distribution varies according to climate at a regional spatial scale and to selective logging history at the landscape scale (Blundo et al. 2015). Finally, variation in forest biomass may affect the phenological timing in DCF (Table 2), i.e. phenological metrics such as season length and start day. Within Chaco forest, areas of sparse vegetation frequently alternate with dense forested areas dominated by two or three tree species, or forested areas dominated by shrubs and cacti (Cabrera 1976, Giménez \& Moglia 2003). In addition, a rainfall gradient decreases from both margins to the centre of this forest type, with mean annual rainfall of $900 \mathrm{~mm}$ (at the west and east sides) to $400 \mathrm{~mm}$ toward the centre (Minetti 1999). These gradients of forest structure and humidity tend to influence the phenology of DCF, mainly the length and the start-day of the growing season. Stands with high biomass are able to maintain high photosynthetic activity at the end of the growing season (Gasparri et al. 2010). These forests are dominated by large trees of hardwooded evergreen species (e.g. Aspidosperma quebrachoblanco, Schinopsis lorentzii and Ziziphus mistol), that are able to exploit deep water and thus have a relatively longer growing season. In contrast, low-biomass plots that result from the removal of large trees and cattle grazing develop a canopy of small trees and shrubs that rely mostly on surface water and rainfall pulses (Gasparri \& Baldi 2013, Gasparri et al. 2010), thus having a shorter season length and later growth start. We suggest that increasing the proportion of plots with changes in forest structure due to recent forest-use will probably increase the relative importance of biomass, or another parameter of structure, to explain phenology within forest types. In this way, identifying key phenological metrics, such as the base value or the peak value (both highly correlated with biomass as shown in Table 1), may be an additional tool for monitoring changes in forest structure related to different forest-use practices across large geographic areas.

There were no relationships between the phenological dynamic and climate or biomass in the semi-deciduous Atlantic forest. The plots studied differed in biomass due mostly to selective logging, but also to species composition changes. Plots with higher biomass were found in warmer areas and were dominated by an evergreen species with relatively high value of wood density (Aspidosperma polyneuron) and the tropical palm Euterpe edulis. Selective logging causes liana and evergreen bamboo encroachment (Campanello et al. 2007), which is likely to mask any phenological signal from trees in remote-sensing studies (Cristiano et al. 2014). Davison et al. (2010) found that communities with high species diversity present poor or null relationships between NDVI dynamics and plant cover. These authors suggest that communities with high species diversity might have mixed signals for vegetation seasonality, phenology and productivity that could outweigh general influences of biomass and climate on these patterns. Consistently, the semi-deciduous Atlantic forest has the highest biodiversity of all subtropical forests studied, and is included among the 25 top biodiversity hotspots in 
the world (Myers et al. 2000). Many tree species in the SAF are shared with seasonally dry tropical forests while other have an Amazonian lineage or link to the Atlantic moist forests (Pennington et al. 2009). The confluence of different phytogeographic domains in this region may contribute to the absence of patterns among the variables studied. A different approach is necessary to accurately predict changes in forest structure and function from remote-sensing analysis in these forests.

In summary, the type of forest use may affect ecosystem functioning through changes in forest structure and species composition in subtropical forests. For example, we found that plots established in old-growth forests of Andean cloud forests have higher above-ground biomass and higher abundance of evergreen tree species in comparison to plots established in disturbed forests with low biomass and higher abundance of deciduous tree species. These changes in forest structure affect phenological signals such as seasonal amplitude or base value, and consequently change leaf phenological patterns in disturbed forest stands. Considering forest biomass in the analysis of the seasonal patterns and trends of EVI dynamics should help to differentiate yearto-year variability from global change effects, e.g. dieoff or land-cover changes (Bradley \& Mustard 2008). Finally, changes in annual precipitation or mean annual temperature as predicted to the study area, or an increase in the forest-use pressure without proper forest management practices can lead to changes in leaf phenological patterns across South American subtropical forests.

\section{ACKNOWLEDGEMENTS}

This study was funded by a postdoctoral grant from CONICET to C. Blundo. We thank two anonymous reviewers for their comments.

\section{LITERATURE CITED}

ARIAS, M. \& BIANCHI, A. R. 1996. Estadísticas climatológicas de la provincia de Salta. Ministerio de la Producción y el Empleo, Dirección de Medio Ambiente y Recursos Naturales e INTA, Salta. 189 pp.

BIANCHI, A. R. \& YÁÑEZ, C. 1992. Las Precipitaciones del Noroeste Argentino. INTA, Salta. 388 pp.

BLUNDO, C. \& MALIZIA, L. R. 2009. Impacto del aprovechamiento forestal en la estructura y diversidad de la Selva Pedemontana. Pp. 387-405 in Brown, A. D., Blendinger, P., Lomáscolo, T. \& García Bes, P. (eds). Selva Pedemontana de las Yungas: historia natural, ecología y manejo de un ecosistema en peligro. Ediciones del Subtrópico, Tucumán.

BLUNDO, C., MALIZIA, L. R., BROWN, A. D. \& BLAKE, J. G. 2012. Tree species distribution in Andean forests: influence of regional and local factors. Journal of Tropical Ecology 28:83-95.
BLUNDO, C., MALIZIA, L. R. \& GONZÁLEZ-ESPINOSA, M. 2015. Distribution of functional traits in subtropical trees across environmental and forest use gradients. Acta Oecologica 69:96-104.

BRADLEY, B. A. \& MUSTARD, J. F. 2008. Comparison of phenology trends by land cover class: a case study in the Great Basin, USA. Global Change Biology 14:334-346.

BRANDO, P. M., GOETZ, S. J., BACCINI, A., NEPSTAD, D. C., BECK, P.S. A. \& CHRISTMAN, M. C. 2010. Seasonal and interannual variability of climate and vegetation indices across the Amazon. Proceedings of the National Academy of Sciences USA 107:1468514690.

BROWN, A.D. 1995. Fitogeografía y conservación de las selvas de montaña del noroeste de Argentina. Pp. 663-672 in Churchill, S. P., Balslev, H., Forero, E. \& Luteyn, J. L. (eds). Biodiversity and conservation of Neotropical montane forests. The New York Botanical Garden, New York.

BROWN, A.D., GRAU, H. R., MALIZIA, L.R. \& GRAU, A. 2001. Argentina. Pp. 623-659 in Kappelle, M. \& Brown, A. D. (eds). Bosques nublados del Neotrópico. Instituto Nacional de Biodiversidad, San José. CABRERA, A. 1976. Regiones fitogeográficas argentinas. Enciclopedia Argentina de Agricultura y Jardinería, Editorial Acme, Buenos Aires. $85 \mathrm{pp}$.

CABRERA, A. \& WILLINK, A. 1980. Biogeografía de América Latina. (Second edition). OEA, Washington, DC. 117 pp.

CAMPANELLO, P. I., GATTI, M. G., ARES, A., MONTTI, L. \& GOLDSTEIN, G. 2007. Tree regeneration and microclimate in a liana and bamboo-dominated semideciduous Atlantic Forest. Forest Ecology and Management 252:108-117.

CHAVE, J., ANDALO, C., BROWN, S., CAIRNS, M. A., CHAMBERS, J. Q., EAMUS, D., FÖLSTER, H., FROMARD, N., HIGUCHI, N., KIRA, T., LESCURE, J. P., NELSON, W., OGAWA, H., PUIG, H., RIERA, B. \& YAMAKURA, T. 2005. Tree allometry and improved estimation of carbon stocks and balance in tropical forests. Oecologia 145:87-99.

CHAVE, J., MULLER-LANDAU, H. C., BAKER, T. R., EASDALE, T. A., TER STEEGE, H. \& WEBB, C.O. 2006. Regional and phylogenetic variation in woody density across neotropical tree species. Ecological Applications 16:2356-2367.

CLARK, J. S., CARPENTER, S. R., BARBER, M., COLLINS, S., DOBSON, A., FOLEY, J. A., LODGE, D. M., PASCUAL, M., PIELKE, R. JR., PIZER, W., PRINGLE, A., REID, W. V., ROSE, K. A., SALA, O., SCHLESINGER, W. H., WALL, D. H. \& WEAR, D. 2001. Ecological forecasts: an emerging imperative. Science 293:657-660.

CRESPO, J. A. 1982. Ecología de la comunidad de mamíferos del Parque Nacional Iguazú, Misiones. Revista del Museo Argentino de Ciencias Naturales "Bernardino Rivadavia" 3:1-162.

CRISTIANO, P. M., MADANES, N., CAMPANELLO, P. I., DI FRANCESCANTONIO, D., RODRIGUEZ, S. A., ZHANG, Y. J., OLIVA CARRASCO, L. \& GOLDSTEIN, G. 2014. High NDVI and potential canopy photosynthesis of South American subtropical forests despite seasonal changes in leaf area index and air temperature. Forests 5:287-308.

CUSTÓDIO TALORA, D. \& MORELLATO, P. C. 2000. Fenologia de espécies arbóreas em floresta de planície litorânea do sudeste do Brasil. Revista Brasileira de Botânica 23 (1): 13-26.

DAVISON, J. E., BRESHEARS, D. D., VAN LEEUWEN, W. J. \& CASADY, G. M. 2010. Remotely sensed vegetation phenology and productivity 
along a climatic gradient: on the value of incorporating the dimension of woody plant cover. Global Ecology and Biogeography 20:101-113.

DE BEURS, K. M. \& HENEBRY, G. M. 2004. Land surface phenology, climatic variation, and institutional change: analyzing agricultural land cover change in Kazakhstan. Remote Sensing of Environment 89:497-509.

DI FRANCESCANTONIO, D. 2017. Características ecológicas, fisiológicas y anatómicas de especies arbóreas del Bosque Atlántico y su relación con los diferentes patrones fenológicos. Tesis doctoral, Universidad de Buenos Aires, Argentina. 128 pp.

EASDALE, T., HEALEY, J. R., GRAU, H. R. \& MALIZIA, A. 2007. Tree life histories in a montane subtropical forest: species differ independently by shade-tolerance, turnover rate and substrate preference. Journal of Ecology 95:1234-1249.

FERRERO, M. E. \& VILLALBA, R. 2009. Potential of Schinopsis lorentzii for dendrochronological studies in subtropical dry Chaco forests of South America. Trees 23:1275-1284.

FRANGI, J. L. \& LUGO, A. E. 1985. Ecosystem dynamics of a subtropical floodplain forest. Ecological Monographs 55:351-369.

GALINDO-LEAL, C. \& GUSMÃO CÂMARA, I. 2003. Atlantic forest hotspot status: an overview. Pp. 3-11 in Galindo-Leal, C. \& Gusmão Câmara, I. (eds). The Atlantic Forest of South America: biodiversity status, threats and outlook (First edition). Island Press, Washington.

GASPARRI, N. I. \& BALDI, G. 2013. Regional patterns and controls of biomass in semiarid woodlands: lessons from the Northern Argentina Dry Chaco. Regional Environmental Change 13:11311144.

GASPARRI, N. I., PARMUCHI, M. G., BONO, J., KARSZENBAUM, H. \& MONTENEGRO, C. L. 2010. Assessing multi-temporal Landsat 7 ETMp images for estimating above-ground biomass in subtropical dry forests of Argentina. Journal of Arid Environments 74:1262-1270.

GIMENEZ, A. M. \& MOGLIA, J. G. 2003. Árboles del Chaco argentino: guía de reconocimiento dendrológico. SAyDS y Facultad de Ciencias forestales UNSE, Santiago del Estero. 307 pp.

GRÖMPING, U. 2006. Relative importance for linear regression in R: The Package relaimpo. Journal of Statistical Software 17:1-27.

HIJMANS, R. J., CAMERON, S. E., PARRA, J. L., JONES, P. G. \& JARVIS, A. 2005. Very high resolution interpolated climate surfaces for global land areas. International Journal of Climatology 25:1965-1978.

HUNZINGER, H. 1997. Hydrology of montane forests in the Sierra de San Javier, Tucumán, Argentina. Mountain Research and Development 17:299-308.

JACKSON, D. A. 1993. Stopping rules in principal components analysis: a comparison of heuristical and statistical approaches. Ecology $74: 2204-2214$.

JOHNSON, J. W. \& LEBRETON, J. M. 2004. History and use of relative importance indices in organizational research. Organizational Research Methods 7:238-257.

JONES, M. O., KIMBALL, J. S. \& NEMANI, R. R. 2014. Asynchronous Amazon forest canopy phenology indicates adaptation to both water and light availability. Environmental Research Letters 9:124021.

JÖNSSON, P. \& EKLUNDH, L. 2004. TIMESAT - a program for analyzing time-series of satellite sensor data. Computers and Geosciences 30:833-845.
KESSLER, M. \& BECK, S. 2001. Bolivia. Pp. 581-622 in Kappelle, M. \& Brown, A. D. (eds). Bosques nublados del Neotrópico. Instituto Nacional de Biodiversidad, San José.

KINDT, R. \& COE, R. 2005. Tree diversity analysis. A manual and software for common statistical methods for ecological and biodiversity studies. World Agroforestry Centre, Nairobi. 196 pp.

KNAPP, A. K., BRIGGS, J. M., COLLINS, S. L., ARCHER, S. R., BRETHARTE, M. S., EWERKS, B. E., PETERS, D. P., YOUNG, D. R., SHAVER, G. R., PENDALL, E. \& CLEARLY, M. 2008. Shrub encroachment in North American grasslands: shifts in growth form dominance rapidly alters control of ecosystem carbon inputs. Global Change Biology 14:615-623.

KOLTUNOV, A., USTIN, S. L., ASNER, G. P. \& FUNG, I. 2009. Selective logging changes forest phenology in the Brazilian Amazon: evidence from MODIS image time series analysis. Remote Sensing of Environment 113:2431-2440.

LEGNAME, P. 1982. Árboles indígenas del noroeste argentino. Opera Lilloana 34:1-226.

LEITE, P. F. \& KLEIN, R. M. 1990. Geografía do Brazil: Regiaõ Sul. Pp. 113-150 in IBGE (ed.). Vegetaçaõ, Vol. 2. Instituto Brasileiro de Geografia e Estadística, Rio de Janeiro.

LIMA PILON, N. A., GIASSI UDULUTSCH, R. \& DURIGAN, G. 2015. Padrões fenológicos de 111 espécies de Cerrado em condições de cultivo. Hoehnea 42:425-443.

LINDEMAN, R. H., MERENDA, P. F. \& GOLD, R. Z. 1980. Introduction to bivariate and multivariate analysis. Scott, Foresman, Glenview.

LINDERMAN, M., ROWHANI, P., BENZ, D., SERNEELS, S. \& LAMBIN, E.F. 2005. Land-cover change and vegetation dynamics across Africa. Journal of Geophysical Research 11010.1029/2004JD005521.

MALIZIA, L., PACHECO, S., BLUNDO, C. \& BROWN, A.D. 2012. Caracterización altitudinal, uso y conservación de las yungas subtropicales de Argentina. Ecosistemas 21:53-73.

MARQUES, M. C. M., ROPER, J. J. \& BAGGIO SALVALAGGIO, A.P. 2004. Phenological patterns among plant life-forms in a subtropical forest in southern Brazil. Plant Ecology 173:203213.

MARTÍN, G. O., NICOSIA, M. G. \& LAGOMARSINO, E. D. 1997. Fenología foliar en leñosas nativas del Chaco semiárido de Tucumán y algunas consideraciones para su aprovechamiento forrajero. Revista Agronómica del Noroeste Argentino 29:65-85.

MINETTI, J. L. 1999. Atlas climático del Noroeste Argentino. Laboratorio Climatológico sudamericano. Fundación ZonCaldenius, Tucumán.

MYERS, N., MITTERMEIER, R. A., MITTERMEIER, C. G., DA FONSECA, G. A. B. \& KENT, J. 2000. Biodiversity hotspots for conservation priorities. Nature 403:853-858.

PARUELO, J. M. \& LAUENROTH, W. K. 1995. Regional patterns of normalized difference vegetation index in North American shrublands and grasslands. Ecology 76:1888-1898.

PENNINGTON, R. T., LAVIN, M. \& OLIVEIRA-FILHO, A. 2009. Woody plant diversity, evolution, and ecology in the tropics: perspectives from seasonally dry tropical forests. Annual Review of Ecology, Evolution, and Systematic 40:437-457.

PIZARRO, M. J., MEZHER, R., MERCURI, P. \& ESPÍNDOLA, A. 2013. Tendencias de extremos climáticos en Argentina. El caso de la provincia 
de Misiones. Informe del Proyecto PNUD ARG/10/013, SAyDS. $12 \mathrm{pp}$.

PRADO, D. 1993. What is the Gran Chaco vegetation in South America? Candollea 48:45-172.

PRINCE, S. D. \& GOWARD, S. N. 1995. Global primary production: a remote sensing approach. Journal of Biogeography 22:815-835.

SARMIENTO, G. 1972. Ecological and floristic convergences between seasonal plant formations of tropical and subtropical South America. Journal of Ecology 60:367-410.

SALAZAR, L. F., NOBRE, C. A. \& OYAMA, M. D. 2007. Climate change consequences on the biome distribution in tropical South America. Geophysical Research Letters 34, L09708.

SUEPA, T., QI, J., LAWAWIROJWONG, S. \& MESSINA, J. 2016. Understanding spatio-temporal variation of vegetation phenology and rainfall seasonality in the monsoon Southeast Asia. Environmental Research 147:621-629.

VAN LEEUWEN, W. J. D., DAVISON, J. E., CASADY, G. M. \& MARCH, S. E. 2010. Phenological characterization of Desert Sky Island vegetation communities with remotely sensed and climate time series data. Remote Sensing 2:388-415.

WEAVER, P. L. 2000. Elfin woodland recovery 30 years after a plane wreck in Puerto Rico's Luquillo mountains. Caribbean Journal of Science 36:1-9.
WERNECK, F. P., COSTA, G. C., COLLI, G. R., PRADO, D. E. \& SITES, J. W. 2011. Revisiting the historical distribution of seasonally dry tropical forests: new insights based on palaeodistribution modeling and palynological evidence. Global Ecology and Biogeography 20:271-288.

WESSELS, K., STEENKAMP, K., VON MALTITZ, G. \& ARCHIBALD, S. 2011. Remotely sensed vegetation phenology for describing and predicting the biomes of South Africa. Applied Vegetation Science 14:49-66.

ZHANG, X. Y., FRIEDL, M. A., SCHAAF, C.B., STRAHLER, A. H. \& LIU, Z. 2005. Monitoring the response of vegetation phenology to precipitation in Africa by coupling MODIS and TRMM instruments. Journal of Geophysical Research 110: D12103.

ZHANG, X. Y., FRIEDL, M. A. \& SCHAAF, C. B. 2006. Global vegetation phenology from moderate resolution Imaging Spectroradiometer (MODIS): evaluation of global patterns and comparison with in situ measurements. Journal of Geophysical Research 111, G04017.

ZHANG, Y. J., CRISTIANO, P. M., ZHANG, Y. F., CAMPANELLO, P. I., TAN, Z. H., ZHANG, Y.P., CAO, K. F. \& GOLDSTEIN, G. 2016. Carbon economy of subtropical forests. Pp. 337-355 in Goldstein, G. \& Santiago, L. (eds). Tropical tree physiology: adaptations and responses in a changing environment. Springer International Publishing, Basel. 
Appendix 1. Mean (and range in parentheses) values of rainfall $\left(\mathrm{mm} \mathrm{y}^{-1}\right)$, mean annual temperature (MAT; ${ }^{\circ} \mathrm{C}$ ) and biomass $\left(\mathrm{Mg}\right.$ biomass $\mathrm{ha}^{-1}$ ) for each forest type. Number of plots and biomass are discriminated by forest state: $\mathrm{OGF}=$ old-growth forest, $\mathrm{DF}=$ disturbed forest. F-value from ANOVAs between biomass and forest state for each forest type. Significant level of $\mathrm{P}<0.01\left(^{*}\right)$; $\left.\mathrm{P}<0.001{ }^{(* *}\right) . \mathrm{HMF}=$ high montane forest; $\mathrm{LMF}=$ low montane forest $\mathrm{PF}=$ premontane forests; $\mathrm{DCF}=$ dry Chaco forest; $\mathrm{SAF}=$ semi-deciduous Atlantic forest.

\begin{tabular}{lcccccc}
\hline Forest type & Rainfall & MAT & Forest state & $\mathrm{N}^{\circ}$ plots & Biomass & F-value \\
\hline HMF & 719 & 15.7 & OGF & 15 & 346 & 0.86 \\
& $(487-978)$ & $(13.9-18.4)$ & & & $(181-507)$ & n.s. \\
& & & DF & 8 & 294 & \\
LMF & 889 & 18.9 & OGF & 11 & 363 & $9.8^{*}$ \\
& $(803-1023)$ & $(17.2-20.4)$ & & & $(214-461)$ & \\
& & & DF & 7 & 253 & \\
& & & & & $(134-323)$ & \\
PF & 920 & 21.0 & OGF & 10 & 380 & $10.1^{*}$ \\
& $(673-1184)$ & $(19.1-22.4)$ & & & $(251-496)$ & \\
& & & DF & 10 & 269 & \\
& & & & & $(102-344)$ & \\
DCF & 739 & 22.6 & OGF & 19 & 129.9 & $14.8^{* *}$ \\
& $(621-892)$ & $(21.6-23.2)$ & & & $(95.9-213)$ & \\
& & & DF & 31 & 98.2 & \\
& & & & & $(39.8-149)$ & \\
SAF & 1743 & 19.1 & OGF & 6 & 462.7 & $19.7^{* *}$ \\
& $(1725-1774)$ & $(17.6-21.4)$ & DF & 14 & 292.3 & \\
& & & & & $(200-424)$ & \\
\hline
\end{tabular}

Appendix 2. Coefficients of correlations between NMDS dimensions (1 and 2) at the plot-scores level with biomass ( $\mathrm{Mg}$ Biomass ha $\left.{ }^{-1}\right)$, and at the species-scores level with wood density $\left(\mathrm{g} \mathrm{cm}^{-3}\right)$ and with leaf phenology (deciduous $=1$; semi-deciduous $=2$; evergreen $=3$ ) HMF $=$ high montane forest; $\mathrm{LMF}=$ low montane forest; $\mathrm{PF}=$ premontane forests; $\mathrm{DCF}=$ dry Chaco forest; $\mathrm{SAF}=$ semi-deciduous Atlantic forest. Significance levels: ${ }^{*} \mathrm{P}<0.05 ;{ }^{* *} \mathrm{P}<0.01$; $^{* *} \mathrm{P}<0.001$.

\begin{tabular}{lcccc}
\hline & & & \multicolumn{2}{c}{ Species scores } \\
\cline { 3 - 5 } Forest type & NMDS & Plot scores & Wood & $\begin{array}{c}\text { Leaf } \\
\text { phenology }\end{array}$ \\
\hline HMF & Dimensions & $-0.60^{* *}$ & -0.13 & $-0.32^{*}$ \\
& 1 & 0.09 & -0.06 & -0.02 \\
LMF & 2 & 0.43 & 0.07 & 0.21 \\
& 1 & 0.41 & -0.13 & $-0.25^{*}$ \\
PF & 2 & -0.14 & -0.15 & $0.41^{* * *}$ \\
& 1 & $-0.57^{* *}$ & 0.09 & -0.03 \\
DCF & 2 & 0.03 & 0.02 & $0.42^{* * *}$ \\
& 1 & 0.12 & $0.34^{*}$ & -0.03 \\
SAF & 2 & $-0.48^{*}$ & $0.40^{* * *}$ & -0.02 \\
& 1 & $0.47^{*}$ & 0.07 & 0.08 \\
\hline
\end{tabular}

